\title{
Metal-Matrix Composites and Thermal Spray Coatings for Earth Moving Machines Quarter 1 Report
}

\author{
Reporting Period Start Date: 02/07/01 \\ Reporting Period End Date: 03/31/01 \\ Principal Author: Matthew T. Kiser
}

July 2001

DOE Award: DE-FC26-01NT41054

Caterpillar Inc.

\author{
Technical Center - E - 854 \\ PO Box 1875 \\ Peoria, IL 61656-1875
}

This report was prepared as an account of work sponsored by an agency of the United States Government. Neither the United States Government nor any agency thereof, nor any of their employees, makes any warranty, express or implied, or assumes any legal liability or responsibility for the accuracy, completeness, or usefulness of any information, apparatus, product, or process disclosed, or represents that its use would not infringe privately owned rights. Reference herein to any specific commercial product, process, or services by trade name, trademark, manufacturer, or otherwise does not necessarily constitute or imply its endorsement, recommendation, or favoring by the United States Government or any agency thereof. The views and opinions of authors expressed herein do not necessarily state or reflect those of the United States Government or any agency thereof. 


\title{
Metal-Matrix Composites and Thermal Spray Coatings for Earth Moving Machines Quarter 1 Report
}

\begin{abstract}
:
First quarter activities were limited to initial project discussions, laboratory preparation, and some initial coupon preparation. Technical discussion were held with the subcontractors to clearly define their roll in the project. Detailed preparation of the pressure casting lab were started. Initial test coupons were sprayed and provided to Oak Ridge National Lab for infrared lamp fusion trials.

\section{Introduction}

This project has two parallel thrusts, (1) developing a cost effective, pressure assisted casting process and optimal structure for abrasion resistant steel metal-matrix composites, and (2) developing a process to create dense, metallurgically-bonded abrasion resistant thermal spray coatings. It is felt that these parallel thrusts are required to address the diverse wear modes and component function requirements of mining machines. Experience is continuing to show that the advanced materials being explored will be required to consistently provide a greater than $2 x$ increase in component wear life. Final contractual documents for this project were signed by Caterpillar on February $28^{\text {th }}$. This closure date delayed the project start, however some preparatory elements were pursued in anticipation of the project start.
\end{abstract}

\section{Experimental}

Steel Metal Matrix Composites Travel was conducted to the University of California at Santa Barbara in order to introduce them to the project and discuss their roll. UCSB will be working on two elements of the steel matrix composite project. The first area of study will look at the infiltration and wetting characteristics, as well as resulting particle-matrix interfacial characteristics of different hard particle and particle coating schemes. The second element will come as pressure cast composites are produced at Caterpillar. UCSB will evaluate the fracture toughness and fracture characteristics of the composites too provide further guidance on particle and matrix choice. Subcontract negotiations with UCSB were started.

Preparations of the pressure casting lab at the Caterpillar Technical Center actually started last year, as part of a Caterpillar internally funded effort. At that time tooling was fabricated for the initial pressure casting experiments. A schematic drawing of the tooling and description is provided in the appendix. A small induction melting furnace was ordered for the lab and will be purchased with Caterpillar capital funds, entirely outside of this project. 


\section{Thermal Spray Coatings}

Discussions were held late in 2000 with Craig Blue of Oak Ridge National Lab regarding infrared lap processing and capabilities. In the first quarter of 2001 coupons were prepared for initial high-density infrared processing trials at ORNL. A description of the materials and spray processes used for the initial coupons is provided in the appendix.

\section{Results and Discussion}

At this time there are not results to discuss

\section{Conclusions \& Future Work}

For steel MMCs casting lab preparation will continue through the second quarter, with the expected installation of the induction melting furnace in July. Work will begin on hard particle selection and identification of potential coatings. Investigation will also continue on methods to create hard particle preforms, building off of prior work at Caterpillar.

For thermal spray coatings, it is expected that ORNL will be able to perform initial infrared lamp processing trials in the $2^{\text {nd }}$ quarter 